\title{
Value Added Tax Planning on The Transfer of Outsourcing Services (Case Study: CJ Enterprise)
}

\author{
Titi Muswati Putranti ${ }^{1}$, Kirana Noviawan Putri ${ }^{2}$ \\ \{titi.putranti@gmail.com 1, kirana.putri97@gmail.com²\} \\ Universitas Indoensia, Depok, West Jawa, Indonesia ${ }^{1}$, Universitas Indoensia, Depok, West Jawa, \\ Indonesia $^{2}$
}

\begin{abstract}
The presence of two tax basis for VAT on transfer of outsourcing services allows Taxable Entrepreneur for VAT purposes to plan their tax planning. This study aims to analyzes CJ enterprise's VAT planning on the determination of a tax basis, reviews it from neutrality and efficiency principles, and cognizes the obstacles they are facing. This study used a qualitative approach with in-depth interview data collection techniques and literature study. The result shows that clients are allowed to choose between the two tax basis. VAT calculated replacement tax base because the familiarity of tax administration. CJ enterprise performs four steps of VAT planning and complies the three requirements of good tax planning. In different circumstances, CJ enterprise's VAT planning complies neutrality principle and is not conform with the efficiency principle. The obstacle CJ enterprise faces is the delay of services payment, also cause CJ enterprise to bail out payments of VAT.
\end{abstract}

Keywords Tax planning, value-added tax, taxable base, outsourcing services:

\section{Introduction}

Increasing business competition in the era of globalization, makes existing industries demanded to be flexible and quick to respond to markets so that these industries can provide goods and services with international standards. This can be done by minimizing operational expenses that are considered unnecessary and maximizing the functions and benefits of the costs incurred [1]. One alternative is using human resources through outsourcing. Using outsourcing systems, companies can concentrate on processes or activities to create products and services related to core business. So the company can produce a number of quality products and services with high competitiveness in the market. This system also allows the efficiency of production costs by saving expenses in financing the human resources working in the company concerned [3]. These reasons make outsourcing services increasingly popular and chosen as an alternative company to save labor costs.

Under Article 66 of Law Number 13 the Year 2003 concerning Manpower states that workers from workers' service providers may not be used by employers to carry out main activities or activities that are directly related to the production process, except for supporting service activities or activities that are not directly related with the production process [4]. 
Under Law Number 42 of 2009 concerning Value Added Tax (VAT Law), labor services are services that are not subject to Value Added Tax (VAT) [5]. The implementation of those provisions regulated under Minister of Finance Regulation No. 83 / PMK.03 / 2012 (PMK 83 of 2012) concerning Criteria and/or Details of Labor Services That Are Not Subject to VAT. Article 3 paragraph (1) of PMK 83 of 2012 mentioned that groups of labor services that are not subject to VAT include: a) labor services; b) labor supply services provided that the employer providing labor is not responsible for the work output of the workforce, and; c) providing training services for workers.

Failing to meet these criteria, labor service will be subject to VAT. Outsourcing service, which is a labor supply service that is directly responsible for the work output of the workforce, are taxable services subject to VAT at a rate of $10 \%$. Therefore, the person or entity who delivers taxable service has become a taxable entrepreneur. The VAT is calculated by multiplying the rate of $10 \%$ of the taxable base.

In accordance with Article 4 paragraph (3) of PMK 83 of 2012, the taxable base of labor supply is stated as replacement, which covers all bills requested or should be requested by service employers for the supply of services for providing labor to service users, including compensation received by workers in the form of salaries, wages, honorariums, benefits, and the like. However, if the outsourced entrepreneur can specify in the tax invoice by separating between the bill for the delivery of labor supply services received by the service entrepreneur and the compensation received by the labor, then the taxable base used is another value. Another value intended is all bills requested or should be sought by service employers for the delivery of services providing labor to service users, not including the benefits received by workers in the form of salaries, wages, honorariums, benefits, and the like.

As a profit-oriented entity, the company usually will minimize the tax burden by exploiting the weaknesses of existing regulations by tax planning. The term tax planning includes strategic structuring aimed at reducing tax liabilities, and tax planning carried out by a company is permitted by the government. Following Article 4 of PMK 83 of 2012, there are two types of the taxable base, namely replacement and other values [7]. The difference between the two bases for imposition will undoubtedly affect the amount of the VAT payable. The existence of two taxable bases from the provisions as mentioned above, the company which is engaged as an agency providing outsourcing services, can minimize its tax burden from this loophole.

The existence of these two taxable bases also provides choices for entrepreneurs in deciding which taxable base they want to choose. Therefore, this regulation can override the principle of neutrality and create distortions that affect the choice of taxable entrepreneurs in calculating the VAT. On the other hand, these two taxable based cause significant differences in VAT payable so that efficiency must be assessed. The following is an example of calculating the imposition of VAT on outsourcing services using both taxable based.

Table 1 Illustration of the taxable base

\begin{tabular}{|c|c|}
\hline In the form of Replacement & In the form of other value \\
\hline $\begin{array}{l}\text { Reimbursement: } \\
150.000 .000 \\
\text { VAT: } 150.000 .000 \times 10 \%=\end{array}$ & $\begin{array}{l}\text { Salary and allowance: } \\
135.000 .000 \\
\text { Management Fee: } \\
15.000 .000 \\
\text { VAT: } 10 \% \times 15.000 .000= \\
1.500 .000\end{array}$ \\
\hline
\end{tabular}

Source: CJ Enterprise Tax Invoice with Author calculation (2019) 
Table 1 shows that there is a significant difference in the VAT calculation between replacement and other values as a taxable base. The difference in the value of the VAT due to the emergence of the efforts made by the company in streamlining the tax burden. These efforts are a form of tax planning, which is carried out thoroughly and continuously by taxable entrepreneurs so that all matters relating to taxation can be adequately managed, economically, effectively, and efficiently. The purpose of this paper is to analyze the tax planning carried out by an outsourcing company in determining a taxable base, the case study of PT CJ. PT CJ chosen to be the case study of this research because they allow their clients to choose the tax basis, meanwhile in the normal circumstances usually the enterprise will choose the tax basis by themselves.

Four essential principles to consider in designing a tax system are equity, revenue productivity, ease of administration, and neutrality. This study, will analysis the VAT policy on outsourcing services using the two principles, i.e., efficiency and neutrality principle. From the taxpayers' point of view, efficiency if the costs incurred by taxpayers to fulfill their tax obligations can be as minimum as possible. Compliance costs are part of administrative or administrative burdens borne by the taxpayer in carrying out tax obligations and can be incurred by third parties as parties who are given obligations to collect/deduct taxes. The principle of neutrality states that taxes must be free from distortions, both distortion of consumption and distortion of production and other economic factors. Thus, taxes should not affect people's choices for consumption, nor do they affect producers in producing goods and services, nor do they reduce people's enthusiasm for work [8].

Tax planning is a common thing done by companies to minimize the tax burden and to increase its effectiveness. Tax planning is the first step in tax management [10]. Taxation management can also be interpreted as a comprehensive effort carried out by the manager of a company or organization with the aim that matters relating to taxation from the company or organization can be managed appropriately, efficiently, and economically, so that it can provide maximum contribution to the company [7]. Tax planning is the first stage to carry out a systematic analysis of various alternative optimum tax treatment [10].

There are three requirements for whether tax planning is proper or not. First, it does not violate taxation provisions. Second, the business makes sense and is an integral part of the company's overall planning (global strategy) both long term and short term. Third, supported by adequate supporting evidence, for example, with the support of agreements, invoices, and accounting treatment [11].

There are five stages for doing VAT planning, which should be done by Entrepreneurs. (1) analysis of the existing database, (2) design of one or more possible tax plans, is the making of tax planning models that are intended as alternatives to determine which tax plan is more used so as to produce the most efficient and effective option when applied, (3) evaluating a tax plan, is a stage that also covers the phase of tax control, (4) debugging the tax plan, is a stage that carries out supervision or controlling, (5) updating the tax plan, carried out with concern in accordance with the latest provisions [12].

Value Added is the value that a producer adds to the purchase value or the factors of material production, before the sale of the product or service. Added value can be seen in terms of wages added to profits, or viewed from the output side minus input. Value-added tax is a tax that is imposed on value-added to the company in which the product is the company's production. Value-added can be seen either as a difference from the value of a company's sales to the number of its purchases or is the total value of wages, profits, rental values, interest, and other payments that are not subject to taxation in a certain period [9]. 
VAT calculates from taxable base $\mathrm{x}$ rate. The taxable base is the final price of goods and services, including all margins or profits from wholesale and retail trade [2]. The taxable base also stated as the amount of the selling price, replacement value, import value, export value, or other value used as the basis for calculating the tax payable. In the Minister Finance Decree No 83 of 2012, it is explained that there are two taxable based, namely replacement and other values.

\section{Methodology}

The research used the qualitative approach because authors try to get a comprehensive understanding of VAT planning on outsourcing service company by taking a case study at one of the outsourcing companies, which is PT CJ. PT CJ chosen to be the case study of this research because they allow their clients to choose the tax basis, meanwhile in the normal circumstances usually the enterprise will choose the tax basis by themselves. This study aims to analyze the differences in the treatment of VAT taxable base on calculating the VAT on outsourcing services. This research used primary data of the sales from the PT CJ as the case study. Data collection is conducted through literature studies and in-depth interviews with some informants. The interview is performed using an unstructured interview with the Directorate General of Tax, the Fiscal Policy Agency, PT CJ as the outsourcing company, academics. Site research conducted in Jakarta for the period of 2018. The research also use a qualitative analysis technique, which consist of several activities namely, collecting data and information from the field, making the data into several categories, turning the data into stories and write them into text.

\section{Result}

PT CJ is an outsourcing service provider who becomes the case study in this research. As a taxable entrepreneur, PT CJ has an obligation to collect, pay and report the VATable. There are four steps of tax planning in determining the taxable base carried out by PT CJ. The taxable base determination process starts at the negotiation process. In the auction process, PT CJ provides offers through the "Lembaga Pengadaan Secara Elektronik" or known as the e-procurement website. Meanwhile, if PT CJ gets the client through the network, PT CJ will provide a presentation on the company profile followed by a negotiation process, and ends with the signing of the contract.

In the negotiation process, clients are allowed to choose between the two taxable bases. During the years of PT CJ's business, all service users use the base in the form of replacement, which includes all bills demanded by service employers, that is PT CJ for the delivery of services providing labor to service users, including the compensation received by workers in the form of salary, wages honorarium, benefits and the like. From one of the interviews with PT CJ's client, PT Z, the taxable base was used because of the habit of the taxable base chosen from the beginning of PT Z's transaction with PT CJ in 2009 in the form 
of replacement. The stages of tax planning carried out by PT CJ in determining the taxable base, although not coherent, still do not affect tax planning.

PT CJ's administration has maintained their book keeping on track. In performing their tax planning, PT CJ always fulfill tax obligation on time and PT CJ always keep their supporting documents related to their transaction routinely. Administratively, PT CJ able to separate between management fee received by the company and salary of the outsourcing labor.

\section{Discussions}

PT CJ has fulfilled the three requirements of good tax planning. When PT CJ determining the taxable base does not violate the law. Even though PT CJ is administratively able to separate between the invoice for the supply of labor services received by the service employer and the compensation received by the labor, but because in the contract law stated in the agreement cooperation between the two parties determines to use the taxable base in the form of reimbursement, the transaction does not violate the applicable provisions. Besides, entrepreneurs have the freedom to choose to use the taxable base used, depending on the conditions of each company. Furthermore, PT CJ's plan is consistent with the company's global strategy so that it makes business sense. Finally, PT CJ's planning in determining the taxable base is supported by valid evidence, in the form of receipts, contracts, invoices, tax invoices, job handover, and so forth.

VAT planning conducted by PT CJ aims to avoid the risk of inspection. PT CJ also always fulfills tax obligations, especially VAT, in a timely manner, to prevent the burden of tax sanctions that can be avoided. The fulfillment of tax obligations under predetermined procedures has an essential role in the success of a tax plan and is one of the strategies suggested for those who are administratively not ready to face the examination.

Two basic principles in VAT planning, such as efficiency and neutrality, are essential principles to consider. If the principle of efficiency is not held firmly, there will be waste and will affect the smooth achievement of management goals. While the principle of neutrality has a vital role so that taxation of goods and services does not affect people's choices in consuming or producing these goods and services.

As a party who legally designated as a VAT collector and has the responsibility to collect, pay and report taxes according to the VAT Act, PT CJ can also bear the compliance costs arising from each service transaction that contains VAT element. Using the concept of other value of a taxable base would meet the efficiency. This approach is based on financial conditions, especially the cash flow of PT CJ. In this case study, cash flow owned by PT CJ was delayed when service users did not pay the bills that were sent to them. This illustrates that in the year, there will be a cash flow gap, where the company's cash condition is insufficient to cover all expenditure items that occur within the company. So with the condition of cash flow owned by PT CJ, it would be better if PT CJ as a Value Added Tax collector could help minimize the burden so that it would not burden PT CJ in fulfilling its VAT obligations.

Calculating VATable using other values is calculated by $1 \%$ of the reimbursement. Therefore using other value as a tax basis would be more efficient if compared to using a 
taxable replacement base, as it presents a smaller VAT payable. It consequences, as the VAT is an indirect tax that is not directly borne by the Seller. But, both using taxable base on reimbursement and other value are almost similar because each of them can be credited against the output tax.

If PT CJ uses replacement as a tax basis, and the service user does not pay its obligations after maturity, PT CJ must bear a large compliance costs to cover the payment of VAT for each time. Meanwhile, if PT CJ uses a tax basis in the form of other values, PT CJ does not need to bear compliance costs that are too large when the service user has not paid its obligations. Thus, the principle of efficiency will be met if the output tax is calculated using a tax basis in the form of another value.

VAT planning in determining the tax base for the outsourcing of services performed by PT CJ is still meet the neutrality principle. This is based on the existence of negotiations in the process of determining the chosen taxable base, which does not distort the public to consume outsourcing services that PT CJ has surrendered nor distorted the outsourcing service provider, PT CJ, in submitting their services. Also, despite the negotiations in determining the taxable base for outsourcing services, it has the effect of distorting. However, in the taxation provisions, it is a legal thing to do as long as the determination of the taxable base remains in accordance with the provisions of the Minister of Finance Regulation No. 83 of 2012.

The development of outsourcing service companies from year to year continues to experience rapid growth. One of them is caused by the ease of procedures for establishing an outsourcing service company and not requiring a lot of capital in its establishment. However, problems in the VAT planning process can occur if the outsourcing service company has insufficient capital.

The problem will arise if the credit transaction and bill to the outsourcing service user company has been sent, but the service user company has not paid its obligations. In terms of value-added tax planning, this causes outsourcing service companies to have to cover the payment of value-added tax. In practice, if a service delivery has been completed, PT CJ will issue an invoice to the service user to collect the payment. But what happens is that the client does not pay his obligations on time, and even tends to delay payment until several months after maturity. This causes PT CJ to bail out in advance payments to outsourced workers and also includes VAT payments.

\section{Conclusions}

VAT planning conducted by PT CJ in determining the taxable base occurred in the negotiation process, and clients are allowed to choose between the two types of taxable bases. During PT CJ's business, all service users use a taxable base in the form of replacement. This was motivated because of the customary administration of each transaction carried out, and the existence of more significant input tax for the buyer. The steps undertaken are in the form of analysis of each component of data, designing two tax plans, evaluating the plan, and summarizing the VAT planning following the latest provisions. The strategy undertaken by PT $\mathrm{CJ}$ in VAT planning leads to avoidance of tax audits. Also, the VAT planning that PT CJ did in determining the taxable base met all three requirements for good tax planning. 
When viewed from the principle of efficiency and neutrality, PT CJ did in determining the taxable base was inefficient planning because entrepreneurs had to spend more money because they had to participate in bailout VAT payments from delinquent clients. Meanwhile, when viewed from the principle of neutrality, the VAT planning in determining the taxable base conducted by PT CJ has fulfilled it. This is because even though there was a negotiation in the process of deciding the chosen taxable base, it did not give distortion to the public to consume the outsourcing services that PT CJ gave up. It also applies to the contrary, the existence of this negotiation does not distort outsourcing service providers, namely PT CJ, in submitting their services.

The obstacle that PT CJ faced in VAT Planning was due to the existence of clients from PT CJ, who were in arrears for up to two to three months. The late payment caused delays in the cash flow of PT CJ. Besides, late payments also caused PT CJ to cover payment of VAT. This condition is quite burdensome for PT CJ in their financial side.

\section{References}

[1] Kompas: Prepare HR, Break Free Competition (Siapkan SDM, Mendobrak Persaingan Bebas!).

https://edukasi.kompas.com/read/2015/05/20/14382291/Siapkan.SDM.Mendobrak.Persaingan. Pasar.Bebas. Acessed on 18 December 2018 17.00.

[2] Le, Tuan M.: Estimating The VAT Base: Method and Application. Tax Notes International, 46, pp. 203. (2007)

[3] Masruhoh, Fernanda, F., \& Wibowo, T.: Cost Efficiency Analysis of the Decision on the Use of Outsourcing in the Cleaning Service and Catering Sector at PT Kuwera Jaya (Analisis Efisiensi Biaya Terhadap Keputusan Penggunaan Outsourcing Bidang Cleaning Service dan Catering Pada PT Kuwera Jaya. Journal The Winners, 15, pp. 35, Jakarta (2015)

[4] Republik Indonesia, Law No. 13 Year 2003 regarding Employment

[5] Republik Indoneisa, Law No. 42 Year 2009 regarding VAT and Sales Tax on Luxury Goods

[6] Republik Indonesia, Minister of Finance Degree No. 83 Year 2012 regarding Criteria and / or Workforce Services Details Not Subject to VAT

[7] Pohan, C. A.: VAT: Theory, Concept, and Implementation of VAT. Gramedia Pustaka. pp. 4 -21, Jakarta (2016)

[8] Rosdiana, H., \& Irianto, E. S: Introduction to Tax Science: Policy and Implementation in Indonesia, PT RajaGrafindo Persada. pp. 157-180, Jakarta (2012).

[9] Rosdiana, Haula, Edi Slamet Irianto, Titi Muswati Putranti: Theory of VAT: Policy and Implementation in Indonesia.Ghalia Indonesia. pp. 168, Bogor (2011)

[10] Rahayu, N., \& Santoso, I.: Corporate Tax Management. Observation and Research of Taxation (Ortax). pp. 15, Jakarta (2013)

[11] Suandy, E.: Tax Planning. Salemba Empat. pp 6-23, Jakarta (2011)

[12] Spitz, B.: International Tax Planning (2nd ed.). Butterworth \& Co Publishers Ltd. pp. 86, United Kingdom (1983) 